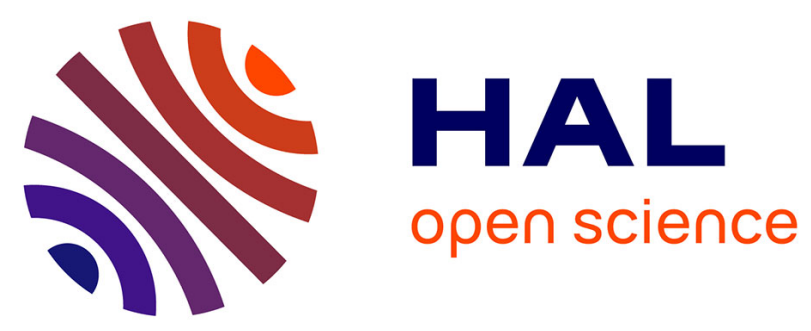

\title{
Participation and earnings of older people in Argentina: nice work if you can get it?
}

Armando Barrientos

\section{To cite this version:}

Armando Barrientos. Participation and earnings of older people in Argentina: nice work if you can get it?. The Journal of Development Studies, 2011, 47 (07), pp.1061-1079. 10.1080/00220388.2010.514333 . hal-00720854

\section{HAL Id: hal-00720854 \\ https://hal.science/hal-00720854}

Submitted on 26 Jul 2012

HAL is a multi-disciplinary open access archive for the deposit and dissemination of scientific research documents, whether they are published or not. The documents may come from teaching and research institutions in France or abroad, or from public or private research centers.
L'archive ouverte pluridisciplinaire HAL, est destinée au dépôt et à la diffusion de documents scientifiques de niveau recherche, publiés ou non, émanant des établissements d'enseignement et de recherche français ou étrangers, des laboratoires publics ou privés. 


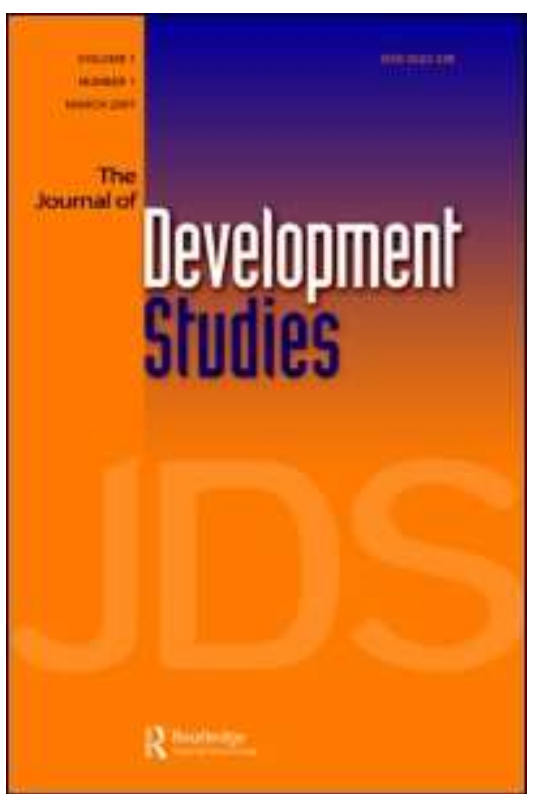

\section{Participation and earnings of older people in Argentina: nice work if you can get it?}

\begin{tabular}{|r|l|}
\hline Journal: & Journal of Development Studies \\
\hline Manuscript ID: & FJDS-2009-Sep-0037.R1 \\
\hline Manuscript Type: & Original Manuscripts \\
\hline Keywords: & $\begin{array}{l}\text { Employment Trends < Employment and Law, South America < } \\
\text { Geographical Area, Poverty < Social Issues, Human Security < } \\
\text { Social Issues }\end{array}$ \\
\hline \multicolumn{2}{|l}{} \\
\hline
\end{tabular}

\section{SCHOLARONE \\ Manuscripts}




\title{
Participation and earnings of older people in Argentina: nice work if you can get it?
}

\begin{abstract}
:
The paper explores the potential contribution of better labour market participation among older people in Argentina to addressing old age poverty and vulnerability. The acute financial crisis in 2001 led to a steep rise in poverty and renewed concerns over the deterioration of old age support. Broadly, two main strategies took shape: to strengthen pension provision for poorer and vulnerable older people, and to improve their labour market participation. Using data from a dedicated survey of older people, the paper tests the feasibility and effectiveness of the second strategy through a detailed analysis of the labour market participation and earnings of older people in Argentina.
\end{abstract}

\section{INTRODUCTION}

The main objective of this paper is to assess the contribution which improved labour market participation among older people in Argentina could make to an effective strategy to address old age poverty and vulnerability. Argentina has a demographic profile comparable to that of Southern European countries and one of the oldest social security systems in Latin America. Successive crises, labour market liberalisation, and social security reform in the 1990s undermined the reach and effectiveness of old age income security (Bertranou and Sanchez 2003; Gill, Packard and Yermo 2004). The acute financial crisis in 2001, and the steep rise in poverty it produced, led to renewed concerns with the deterioration of old age support. Broadly, two main strategies took shape: to strengthen pension provision for poorer and vulnerable older people, and to improve their labour market participation. This paper tests the feasibility and effectiveness of the second strategy through an analysis of the labour market participation and earnings of older people in Argentina. 
Labour market liberalisation and social pension reform in the 1990s in Argentina contributed to a rapid decline in the coverage of the social security system. Whereas in 1993, 77 percent of the population aged 65 and over were receiving a retirement pension, and 87.5 percent were receiving some form of old age support; by 2001 these measures of coverage had declined to 66.5 percent and 77 percent respectively (Rofman 2004). The deterioration in the reach of social security accompanied worsening social indicators. Between March 1994 and March 2000, the poverty headcount rate almost doubled from just above 15 percent to just below 30 percent (Maurizio 2009). The crisis which followed the abandonment of convertibility in 2001 led to a further steep rise in poverty, from 35.9 percent in March 2001 to 57.5 percent in October 2002. Rising unemployment and a sharp contraction in earnings were mainly responsible for the rise in poverty. The recovery in employment after 2002, together with improved social policies, including pensions, have successfully reversed the poverty trend. The crisis sharpened concerns with the decline in pension coverage and helped delineate two main strategies. Studies looking at the dynamics of poverty during this period found that labour market factors (changes in employment and earnings) and access to social transfers explained the majority of observed exits from poverty in the period following the crisis (Maurizio, Perrot and Villafane 2007). These findings suggest that improvements in the labour force participation of older people and in pension provision could be effective in addressing old age poverty and vulnerability.

There is a growing literature on the effectiveness of non-contributory pensions in reducing poverty in developing countries (Bertranou, Solorio and van Ginneken 2002; Holzman, Robalino and Takayama 2009). Studies of the impact of the Argentina crisis confirmed this. Households with pensioners were less likely to succumb to poverty during the crisis and were more likely to exit poverty after it (Cruces and Wodon 2003; Maurizio 2009). However, older people with no access to pensions had few options to protect themselves against the impact of the crisis.

By contrast, there is very little research on the contribution that improved labour market participation among older people could make to strategies to strengthen old age security. This is the focus of the paper. There is early evidence that labour market participation rates among older groups in Argentina have risen in the period preceding 
and following the crisis. Figure 1 below shows participation rates by age taken from nationwide household surveys covering the period 1997-2004. The datasets are not strictly comparable, and care must be exercised in interpreting the data, but they provide some indication of a rising trend over time, especially for those aged 65 to $75 .{ }^{1}$

(Figure 1 about here)

Few studies have looked at this issue in developing countries. In developed countries, withdrawal from the labour market at late age is largely explained by employmentbased pension systems and public assistance programmes (Gruber and Wise 1999). In low-income countries, the absence of pension systems makes continued employment a necessity for older people, with health factors becoming important later on (Benjamin, Brandt and Fan 2003). In middle-income countries, it is likely that a mix of factors apply. The influence of pension systems on labour market withdrawal is stronger for workers in formal employment, but considerably attenuated for the rest (Clark, York and Anker 1999). Analysis of the labour market participation of older people in Argentina can make an important contribution to the scarce literature by providing a middle-income country perspective.

The paper will take advantage of survey data provided by a the ETEEP Survey (Encuesta a la Tercera Edad sobre Estrategias Previsionales or Survey of Older People's Income Security Strategies). This dedicated survey is a unique source of information on older people in Argentina. Standard household surveys usually yield few observations from older people, and from the very old in particular. The ETEEP sample is comparatively larger, and contains fine grained information on respondents' lifetime pension and employment profiles, thus enabling a more detailed analysis of the factors determining labour market participation.

The paper is organised as follows. Section 1 presents the research strategy, including a description of methods, data and a discussion of relevant literature. Section 2 examines the labour force participation and earnings of older people in Argentina. Section 3 assesses the potential contribution of improved labour force participation as a strategy to address old age poverty and vulnerability and draws out the main 
conclusions and policy implications. A final section summarises the main conclusions.

\section{RESEARCH STRATEGY AND LITERATURE}

This section develops a strategy for the empirical work, reviews the relevant literature and describes the data.

\section{Model}

A starting point is the standard, static, one-period model of labour supply (Pencavel 1986; Blundell and MaCurdy 1998). For an individual i with personal characteristics $X$, which are observed, and unobserved 'tastes' $\varepsilon$, and with a quasi-concave continuous utility function $U$ defined over her consumption of commodities $c$ and hours of work h,

$U_{i}=U_{i}\left(c_{i}, h_{i} ; X_{i}, \varepsilon_{i}\right)$

Given a total time endowment of $T$, which is allocated to market work hours $h$ or to other activities $l$, the linear budget constraint is:

$$
p c_{i}=w h_{i}+y_{i}
$$

where $p$ is the fixed per unit price of commodities $c, w$ is a fixed hourly wage and $y_{i}$ is non-labour income. The individual chooses $c>0$ and $h \geq 0$ to maximise (1) subject to the budget constraint (2). For individuals with positive hours, the familiar first order condition for a constrained maximum indicates that $c$ and $h$ are chosen so that the negative of the marginal rate of substitution $m$ of working hours for commodities equals the real wage.

$\frac{w_{i}}{p}=-m\left(c_{i}, h_{i} ; X_{i}, \varepsilon_{i}\right)$, 
For those with $h=0$, on the other hand, the marginal rate of substitution of working hours for commodities is:

$\frac{w_{i}^{*}}{p}=-m\left(c_{i}, 0 ; X_{i}, \varepsilon_{i}\right)$

and $w_{i}{ }^{*}$ is the reservation wage, that is, the individual $i$ 's implicit valuation of her time at the margin between participating and not participating in the labour market. It follows that

$h_{i}=h_{i}\left(p_{i}, w_{i}, y_{i} ; X_{i}, \varepsilon_{i}\right)>0, \quad$ if $\quad w_{i}>w_{i}^{*}\left(p_{i}, y_{i}, X_{i}, \varepsilon_{i}\right)$

$h_{i}=h_{i}\left(p_{i}, w_{i}, y_{i} ; X_{i}, \varepsilon_{i}\right)=0, \quad$ if $\quad w_{i} \leq w_{i}^{*}\left(p_{i}, y_{i}, X_{i}, \varepsilon_{i}\right)$

To summarise, in this basic model the decision whether to participate in the labour market follows from a comparison made by individuals of the market valuation of the time devoted to paid employment (wage offers) as against their private valuation of this time (reservation wage). If the market valuation is greater than the individual's private evaluation, s/he will have a strong incentive for continuing in employment, and vice-versa. In the context of older people, this framework can incorporate a wide rage of factors influencing their continuation/withdrawal from the labour market. They are discussed briefly below.

\section{Literature}

In developed countries, pension schemes are a dominant factor in determining the labour force participation of older people (Diamond and Gruber 1999). Withdrawal from the labour market is supported and encouraged by old age income support programmes. Pension receipt, usually in the form of an annuity (a regular income for the full lifetime of a beneficiary), raises $y$ and therefore the reservation wage for older workers (Hanoch and Honig 1983; Mitchell and Fields 1984). The strength of the incentives provided by pension schemes in developed countries ensures that retirement and work are to a very large extent non-overlapping states (Hurd 1990b). ${ }^{2}$ In developing countries, limited pension provision reduces incentives for withdrawal 
and enforces continued engagement in employment. A study on rural China finds that rapidly declining fertility and the migration of younger people to the cities forces older people to a lifetime of work, described as 'ceaseless toil' (Benjamin, Brandt and Fan 2003). Withdrawal from the labour market is not a feasible option for older people in rural areas. Middle-income countries probably experience a mix of these two situations. Where pension schemes are in place and cover a large proportion of older people, withdrawal from the labour market is linked to pension receipt (Barrientos 2000; Carvalho 2000b; Bertranou 2001; Camarano and Pasinato 2002), but compared to developed countries, there is significant overlap between pension receipt and participation.

Household characteristics and support are the second most important factor in determining the labour force participation of older people in developing countries. This comes up in different contexts, ${ }^{3}$ for example in studies of the income effects of pensions on living arrangements (Carvalho 2000a), or the extent to which pensioner household dynamics responds to economic conditions (Barrientos 2004).

The health status of older people and other members of their households, has been identified as an important factor. This has been well researched in the context of developed countries (Bound, Schoenbaum, Stinebrickner et al. 1999), but less so in developing countries (Kochar 1999; Parker 1999; Benjamin, Brandt and Fan 2003). Haider and Loughran (2001) find that the probability of men aged 68 and over in the USA being in employment is strongly correlated with wealth, good health, and positive preferences for work. Benjamin et al. (2003) find that the effects of health on labour supply of older people in rural China are complex. On the one hand, poor health reduces time available for work, and productivity, but on the other hand higher health costs, whether actual or expected, encourage continued employment in old age. Their study finds that "declining health explains about half of the decline in hours worked by age seventy" (p.35) in rural areas in China. Parker (1999) estimates that poor health reduces the earnings of older Mexicans by just over a quarter.

Another important set of factors relates to the type of work that older people do, and their employment status. Some authors find a relationship between employment in certain occupations and retirement (Hurd and McGarry 1993; Filer and Petri 1998). 


\section{Methods}

The analysis below should pay particular attention to the labour market opportunities for non-participants. Gronau (1973) developed a methodology for estimating potential earnings of non-participants, from the estimated earnings of participants corrected for participation propensities. This methodology was later refined by Heckman into a two-stage estimation which corrects for selection bias (Heckman 1974, 1976). This issue is especially relevant for studying earnings among older people, as we are only able to observe earnings for a small sub-sample. Estimating a standard wage equation for this sub-sample such as: $\ln w_{i}=B_{X_{i}}+e_{i}$ using OLS produces biased estimates because from (5) above it is apparent that $\left(\mathrm{e}_{\mathrm{i}} \mid \mathrm{w}_{\mathrm{i}}>\mathrm{w}_{\mathrm{i}}{ }_{\mathrm{i}}\right) \neq 0$. Heckman (1976) suggests a two-stage estimation method, in which a probit model of participation yields the inverse Mills' ratio $\lambda$, a measure of the propensity of participation, which is included into the wage equation to provide consistent estimates of the coefficients, as

$\ln w_{i}=\alpha_{i}+B X_{i}+\delta \hat{\lambda}_{i}+v_{i}$

The estimated coefficients from (7) can then be used to predict potential earnings for the full sample. The empirical work below will apply this methodology to construct a measure of potential earnings for both participant and non-participant older people.

\section{Data}

The examination of the labour force participation and earnings of older people relies on data collected in October-November 2003 under the ETEEP Survey (Encuesta a la Tercera Edad sobre Estrategias Previsionales or Survey of Older People's Income Security Strategies). The survey targeted households with a member aged 60 and over in urban areas of Argentina, excluding the Patagonia Region. It interviewed one 
individual aged 60 or over in 3,014 households identified through stratified probabilistic sampling. ${ }^{5}$ The survey instrument contained questions on individual and household characteristics, household income, assets, expenditure, and livelihood strategies; labour and pension history of respondents, and summary information on the economic status and characteristics of other household members. As noted in the Introduction, The ETEEP sample of older people in Argentina is comparatively larger than the coverage of this group in standard household surveys. It also has the very significant advantage of including detailed information on respondents' lifetime pension and employment, absent from standard household survey data. As seen from the analysis below, this information is essential to the study of older people's labour force participation and earnings.

\section{LABOUR FORCE PARTICIPATION AND EARNINGS OF OLDER PEOPLE}

In Argentina, participation in the labour market and pension receipt are overlapping categories. Figure 2 below shows the distribution of respondents in the ETEEP dataset across labour market participation and pension receipt categories. Just under a quarter of the population are active in the labour market (employed and looking for employment), while just over three-quarters are inactive. Those in receipt of a pension benefit, shown by the ellipse and including all pension types, comprise 61 percent, while the residual are non-pensioners. The overlapping categories are important: 6.9 percent are in receipt of a pension and also active in the labour market, while 22.4 percent are inactive and not in receipt of any pension.

(Figure 2 about here)

The ETEEP Survey contains information on respondents' assessment of the main reason behind their pension/participation status. Non-pensioners were asked to select one reason why they had not accessed a pension. Two thirds gave as the main reason the fact that they had not been able to meet eligibility requirements for contributory pensions (the vast majority because they lacked the required contribution history). A minority $(14.7 \%)$ selected as the main reason the fact that they had never worked. 
Respondents in receipt of a pension and active in the labour market were asked to select a reason for continuing in work. The vast majority responded that they continued participating in the labour market because their pension benefits were insufficient to meet their needs $(69.6 \%)^{6}$, with a minority responding that they had a preference for continuing in work (12.4\%). It is clear from these responses that engagement in the labour market is important for their standards of living, but also that a range of other factors contribute directly to this engagement.

\section{Participation}

Analysis of the determinants of the labour force participation of older people proceeds by estimating a probit model of participation as follows:

$$
L P_{i}=\beta_{0}+\mathrm{B} X_{i}+\Gamma Z_{i}+\Psi H_{i}+\Omega O_{i}+\Xi R_{i}+\varepsilon_{i}
$$

Where LP is a $(0,1)$ variable denoting whether the $i$ th respondent participates in the labour market (i.e. if s/he is employed or unemployed and looking for employment), $\mathrm{X}_{\mathrm{i}}$ is a vector of personal and household characteristics, $\mathrm{Z}_{\mathrm{i}}$ is a vector of cash flow gap strategies, $\mathrm{H}_{\mathrm{i}}$ is a vector of health status variables, $\mathrm{O}_{\mathrm{i}}$ is a vector of occupation and employment status characteristics, $R_{i}$ is a vector of region dummies, and $\varepsilon_{i}$ is the error term (variable definitions can be found in Appendix 1).

The full sample includes all respondents aged 60 and over, reflecting the population sampled by the dataset. Other studies have used different age restrictions. Bertranou (2001), for example, estimates a probit model of labour market participation for people aged 55 to 75 . The rationale for the upper age restriction is that few observations are usually available for very advanced ages. Setting a lower age restriction is dependent on the focus of the analysis. In this paper, the objective is to throw light on the labour market participation of older people, and on the extent to which employment constitutes an effective livelihood strategy for households with older people. The analysis therefore focuses on all respondents aged 60 and over. ${ }^{7}$ An advantage of using the full sample in the analysis is that its findings will apply to the older population as a whole. 
The model was estimated on a full sample, and on a sample of males only. Males make up the majority of participants, so the results are unlikely to be substantively different across the two samples; nonetheless it is useful as a check of whether the results are sensitive to the inclusion of a minority of women participants. ${ }^{8}$

The main coefficients of interest are presented in Table 2 below. The Table reports marginal effects.

(Table 2 about here)

As expected, participation declines with age. ${ }^{9}$ Being male is a strong predictor of participation, although this finding is to an extent influenced by the fact that women can access retirement pensions earlier than men, and are more likely to access noncontributory pensions. Self-reported health status is significant, with those who reported good health more likely to be in the labour market, and those with poor health less likely to be in the labour market, compared to those with average health status. The coefficients associated with health status are strongly significant, and robust to the inclusion of different variables in the model, but the marginal effects are not especially large relative to other factors. Participation in the labour market is inversely related to the presence of other pension recipients in the household. ${ }^{10}$

Household exposure to shocks might be a factor in continued employment. Although it is not possible to observe these directly in the survey data, information is available on strategies adopted by households to cope with cash flow gaps, or financial stress. Aggregating three of these strategies (whether households had to borrow from family and friends, or use consumer credit, or sell belongings in the last three months) provides some information on the presence of threats to consumption and on active efforts by households to protect it. The use of multiple strategies can be taken as an indicator of financial stress. Interestingly, labour force participation is positively associated with the number of financial distress strategies used by households. This perhaps suggests that continued work is, to some extent, a response to financial stress, although it is also possible that earnings facilitate access to credit. 
The employment-related coefficients are very important, both because of the strength and significance of the estimated effects, and also because they point to the relevance of a range of factors not typically included in standard household surveys, and therefore seldom included in the estimation of participation models for older people. The estimated coefficients suggest strong path dependence in participation for older people, with very specific features. Labour market participation of people aged 60 and over is inversely related to density of contributions, and positively related to density of employment, over the working life. This confirms that being in work earlier on strengthens attachment to the labour force later on.

Restricting the estimation of the model to males only does not, as expected, change the sign of the estimated effects, but the marginal effects are larger in all cases.

\section{Earnings}

Before moving on to the results from the estimation of the earnings equation, it is necessary to note some issues relating to the earnings measure used. It was constructed by aggregating all monthly earnings from labour, including earnings from dependents and self-employment, earnings from additional employment where relevant, and a self-reported monetary value of in kind labour compensation. Given the high incidence of self-employment in the sample, using this measure of labour income helped to maximise the number of observations with labour earnings. Even so, just below one half of active respondents could be associated with a valid observation for the earnings measure thus constructed. This raised concern over potential biases arising from non-response, but detailed checks on non-response biases confirmed they are not important. ${ }^{11}$ There is no information in the dataset on hours of work, so the estimation of the earnings equation has to rely on this aggregate measure of monthly earnings.

The model estimated is a standard earnings equation augmented by the Heckman correction term:

$$
\ln E_{i}=\alpha_{0}+\mathrm{B} X_{i}+\Psi H_{i}+\Omega O_{i}+\Xi R_{i}+\delta \lambda_{i}+v_{i}
$$


Where $\ln E_{i}$ is the natural $\log$ of the measure of earnings described above, and as above $\mathrm{X}_{\mathrm{i}}$ is a vector of personal and household characteristics, $\mathrm{H}_{\mathrm{i}}$ is a vector of health status variables, $\mathrm{O}_{\mathrm{i}}$ is a vector of occupation and employment status characteristics, $\mathrm{R}_{\mathrm{i}}$ is a vector of region dummies, $\lambda_{i}$ is the inverse Mill's ratio, and $v_{i}$ is the corrected error term. Identification is ensured by the exclusion of the number of financial distress strategies, which is taken to influence participation but not earnings, and by the inclusion of the size of establishment in the last job in the earnings equation but not in the participation equation. The influence of the size of establishment on earnings is well documented in the literature (Evans and Leighton 1989).

As with the participation equation, the earnings model is estimated on the full sample and a sample of males only. The models have reasonably good fit. Table 3 reports on the key coefficients, which are in line with expectations. Earnings decline with age, and are higher for males. They are higher for those with higher education. The health coefficients have the expected sign. Poor health status is associated with lower earnings, while good health status is associated with higher earnings. Selfemployment is associated with lower earnings, and being an employer is associated with higher earnings. Higher lifetime contribution density and employment density are associated with higher earnings. The latter is particularly strong, and shows the impact of both experience and labour force attachment. Interestingly, the size of establishment is negatively correlated with earnings at later ages.

The correction term is significant for the full sample, but not for the male only sample. There are a few other differences to note in the estimates for the male only sample. Having only primary school education significantly reduces the earnings of males; poor health does not significantly affect male earnings; being an employer in the last job significantly increases earnings. On the whole, estimates for the male only sample are not substantially different from those for the full sample.

(Table 3 about here)

The models of participation and earnings estimated in this section provide important information on their main determinants. The next section interrogates these findings, 
in order to test for the potential contribution of improved labour force participation as a strategy to address old age poverty and vulnerability.

\section{IMPROVED PARTICIPATION AS A STRATEGY TO ADDRESS OLD AGE POVERTY?}

The estimates from the models of participation and earnings enable the next step in the analysis, which is to predict earnings for the whole sample. The exercise aims to provide information on potential earnings for the full sample, including nonparticipants. This will make it possible to locate participants in the labour market within the distribution of predicted earnings for the whole sample, and to draw some implications for the feasibility and effectiveness of improved labour force participation as a strategy to address old age poverty and vulnerability.

\section{Locating participants and the distribution of predicted earnings}

The basic model of labour at the start of the paper suggests some hypotheses we could pursue. Firstly, continuation in the labour market results from a comparison of the market valuation of older people's time (wage offers) and their own private valuation of this time (reservation wage). It follows from this that older people with strong economic need are likely to have a low reservation wage; whereas older people with high income or assets are likely to have a high reservation wage. It is not possible to observe wage offers or reservation wages directly, but it is possible to draw inferences from the location of participants in the distribution of potential earnings.

A good range of wage offers would be consistent with an even distribution of participants across potential earnings. At least it should then be possible to observe a good number of workers with a low reservation wage participating in the labour market. Improved participation in the labour market could constitute an effective strategy for poor and vulnerable older people to ensure basic living standards. The presence of generous pension provision for formal sector workers, tied to labour market withdrawal, would skew the distribution of participants towards the lower deciles of the distribution of potential earnings. 
Alternatively, a restricted range of wage offers - effectively pricing out low productivity older workers - would skew the distribution of participants towards the higher deciles of the distribution of potential earnings. Under these conditions, improved participation in the labour market is unlikely to constitute an effective strategy for low income and vulnerable older people.

Figures 3 and 4 show the location of actual participants within the distribution of potential earnings for the full sample and the sample of males only. Figure 3 shows the percentages of respondents within each of the deciles of potential earnings who are participants. Figure 4 shows the percentages of all active respondents to be found in each of the deciles of potential earnings.

(Figures 3 and 4 about here)

As can be seen from the Figures, participants are actually concentrated on the higher deciles of predicted earnings. Taking the information in Figure 3 first, few of those with predicted earnings in the low deciles of predicted earnings are participating in employment. Participation is highest for those in the higher deciles of predicted earnings. The vast majority of respondents predicted to have earnings in the top decile are active (91.7\%) and this also applies to the ninth decile (67.4\%). This is the case when considering the full sample and the sample of males only, although marginally more active males can be found in the lower deciles of predicted earnings.

Figure 4 shows that the majority of respondents participating in the labour force can be found in the higher deciles of predicted earnings. Over three quarters of active respondents can be found in the top three deciles when the full sample is considered. This is attenuated for the male sample, but even then over one half of active males can be found in the top three deciles of predicted earnings.

These findings confirm that participants in the labour market are also those with higher potential productivity. The findings are consistent with labour market conditions in which less productive older workers are filtered out through voluntary or involuntary withdrawals and/or pension incentives. If the sample is restricted to men only, marginally more participants are to be found in the lower deciles of predicted 
earnings than when the full sample is used. This suggests that the opportunities for low productivity males to continue in employment are marginally better than those available to low productivity females, or that females with low potential labour market productivity and/or higher reservation wage are filtered out much earlier. The main conclusion is that only males and females with higher predicted earnings are likely to be in employment in later life. ${ }^{12}$

\section{Implications for appropriate strategies}

The introduction to the paper posed the question of whether improved participation in the labour market among older people is a viable and appropriate strategy to address old age poverty and vulnerability. The findings in this paper suggest that participation in the labour market can be an effective strategy for older people with high potential earnings, but that it is unlikely to be effective for older people with low or average skills and productivity. In particular, improved participation in the labour market is unlikely to be an effective strategy for older women with low or average skills and/or low lifetime engagement in employment.

The opportunities and benefits from 'active' ageing appear to be skewed towards healthier and wealthier old people, at least as far as remunerated work is concerned. The analysis in the paper benefited considerably from the work history information in the ETEEP dataset, as it enabled an examination of the influence of longer term factors. The relevant findings in the paper strongly suggest that policy-makers wishing to enhance opportunities for employment among older people must give consideration to policies that improve health status and continued employment for workers well before retirement age. As younger generations of workers improve their human capital, including education and health endowments, labour force participation might become a more significant strategy for addressing old age poverty, and the opportunities arising from 'active ageing' might become more widely distributed. In the medium and longer term, social investment is a valuable response to population ageing.

The analysis in the paper confirms that strengthening social policies directed at older groups will remain an urgent policy challenge in Argentina in the short term. Since 2005, the Government of Argentina has taken several steps in this direction. In 
January 2005, a Social Protection Inclusion Plan (Plan de Inclusión Previsional) was introduced. It provided a two-year window for age qualified persons lacking social insurance contributions and for contributions-qualified persons just below the retirement age and unemployed, to access a minimum pension. This measure led to an additional 1.4 million individuals accessing pension benefits, equivalent to a 15 percentage point rise in pension coverage, to 78 percent of people aged 65 and over (D'Elia 2007; Maurizio 2009). The Government also introduced legislation enabling self-employed workers to reduce pension arrears, and the level of the minimum pension has been increased significantly in real terms. ${ }^{13}$ The Social Inclusion Protection Plan was designed as a short-term measure to address the deterioration in pension coverage. It has been successful in raising coverage rates, but there are concerns about its implementation and financial sustainability. The Plan excluded the very poorest and those with little engagement in formal employment. This could explain the findings of a study comparing poverty among older people before and after the Plan, confirming a very high incidence of chronic poverty (D'Elia 2007).

There are a number of implications from the analysis in the paper for policy responses to ageing in Argentina. Social transfers to poorer and older people are the most effective strategy to address old age poverty in the short term. Improved participation of older people in the labour force could, however, make an important contribution in the medium and long term, providing that social investment raises skills and health among younger generations.

\section{CONCLUSIONS}

Argentina has one of the longest established old age support systems in Latin America, but successive economic crises, labour market liberalisation, and social security reforms have undermined its reach and effectiveness. The acute financial crisis in 2001 led to rising poverty and unemployment. The recovery shaped two main strategies enabling households to exit poverty: improved employment and earnings, and social transfers. There are some indications that participation rates among older people have been climbing in Argentina. The findings in the paper showed that in 2003 around one in four individuals aged 60 and over were participating in the labour 
force and close to 7 percent in the same age group combined receiving a pension with participating in the labour force. The paper examined whether improvements in labour market attachment among older people could help address old age poverty and vulnerability.

The analysis focused on the labour force participation and earnings of older people, and their determinants. The starting point was a static model of labour supply, in which the decision to continue in employment or withdraw is based on a comparison of the market value of time (wage offers) and the individual's own private valuation of that time (reservation wage). Whilst it is not possible to observe wage offers and reservation wages directly, the approach was to extract relevant information from the observed outcome of the decision. The fact that a minority of older persons are in employment necessitated a two stage estimation to account for selectivity issues. Firstly, a model of labour market participation was estimated, which confirmed that household characteristics, limited access to pensions, health status, and occupational and employment status are the main determinants of participation for this age group. Employment path dependence appears to be an extremely important factor. Higher employment density over the whole working life has a strong effect on continued participation at more advanced ages. This is an important finding, made possible by the fact that the ETEEP dataset includes information on working life histories. The second stage involved the estimation of an earnings model, corrected for participation propensities.

The coefficients from the earnings equation were then used to predict earnings for the full sample of older people. Examining the distribution of labour market participants and not-participants along predicted earnings confirmed that participants are mainly drawn from those with higher potential earnings, with over three quarters of active respondents to be found in the top three deciles of predicted earnings. This is consistent with labour market conditions in which less productive workers are filtered out through voluntary or involuntary withdrawals and/or pension incentives. It is also consistent with limited opportunities for low productivity older workers to continue in employment at later ages. 
The Introduction to the paper posed the question of whether improved participation in the labour market among older people constitutes an effective strategy for addressing old age poverty and vulnerability. The findings in the paper suggest that under current conditions, this would be an effective strategy for older people with high potential earnings, especially males with sustained labour force attachment. However, it is unlikely to be an effective strategy for older people with low potential earnings. In the medium to the long term, improved participation in the labour market could make an important contribution to addressing old age poverty and vulnerability, providing that policies are put in place which enhance the health status and labour force attachment for younger workers. In the short term, strengthening social policies providing income security for poorer and vulnerable older people remains an urgent policy challenge. Since 2005, the Government of Argentina has sought to raise the coverage and value of pensions directed at poorer and more vulnerable older groups.

With rapid population ageing in the South, important lessons can be drawn from Argentina. In the short run, there are few policy options for policy makers concerned with old age poverty and vulnerability. Income transfers to older people remain a primary instrument to address old age poverty and vulnerability. In the medium term, improving the health status and employment prospects of younger workers will pay dividends later on, not only in terms of improved productivity, which helps generate resources to finance higher pension expenditure, but also in terms of facilitating their extended labour force attachment. 


\section{REFERENCES}

Alós, M.; Apella, I.; Grushka, C. and Muinos, M. (2008) Participation of seniors in the Argentinian labour market: An options value model, International Social Security Review, 61 (4), pp. 25-49.

Barrientos, A. (2000) Work, retirement, and vulnerability of older workers in Latin America. What are the lessons for pension design?, Journal of International Development, 12.

Barrientos, A. (2004) Latin America: towards a liberal-informal welfare regime, in I. Gough; Wood, G.; Barrientos, A.; Bevan, P.; David, P. and Room, G. (eds.), Insecurity and welfare regimes in Asia, Africa and Latin America, (Cambridge: Cambridge University Press).

Benjamin, D.; Brandt, L. and Fan, J.-Z. (2003), Ceaseless Toil? Health and Labour Supply of the Elderly in Rural China, mimeo, Toronto: Department of Economics, University of Toronto.

Bertranou, F. (2001) Empleo, Retiro y Vulnerabilidad Socioeconómica de la Población Adulta Mayor en Argentina, mimeo, Cuyo: Universidad Siglo 21.

Bertranou, F. and Sanchez, A. (2003) Características y determinantes de la densidad de aportes a la seguridad social en la Argentina 1994-2001, in Ministerio del Trabajo and OIT (eds.), Historias Laborales de la Seguridad Social, (Buenos Aires: Ministerio del Trabajo), pp. 37-64.

Bertranou, F.; Solorio, C. and van Ginneken, W. (2002) Pensiones no-contributivas y asistenciales. Argentina, Brazil, Chile, Costa Rica y Uruguay, Santiago: ILO.

Blundell, R. and MaCurdy, T. (1998) Labor Supply: A Review of Alternative Approaches, Working Paper W98/18, (London: Institute for Fiscal Studies).

Bound, J.; Schoenbaum, M.; Stinebrickner, T. R. and Waidmann, T. (1999) The dynamic effects of health on the labor force transitions of older workers, Labour Economics, 6, pp. 179-202.

Burtless, G. and Moffitt, R. A. (1985) The Joint Choice of Retirement Age and Postretirement Hours of Work, Journal of Labor Economics, 3 (2), pp. 209-236.

Camarano, A. A. and Pasinato, M. T. (2002), Envelhecimento, condicoes de vida e politica previdenciaria. Como ficam as mulheres?, Discussion Paper 833, (Rio de Janeiro: IPEA).

Carvalho, I. (2000a), Elderly Women and their Living Arrangements, mimeo, (Cambridge MA: MIT).

Carvalho, I. (2000b), Old-Age Benefits and the Labour Supply of Rural Elderly in Brazil, mimeo, (Cambridge MA: MIT).

Clark, R. L.; York, E. A. and Anker, R. (1999) Economic development and labour force participation of older persons, Population Research and Policy Review, 18, pp. 411432.

Cruces, G. and Wodon, Q. (2003) Transient and chronic poverty in turbulent times: Argentina 1995-2002, Economics Bulletin, 9 (3), pp. 1-12.

D'Elia, V. (2007) Pobreza en hogares con adultos mayores: Un análisis a partir del Plan de Inclusión Social, Report, (Buenos Aires: ANSES).

Diamond, P. and Gruber, J. (1999) Social Security and retirement in the United States, in J. Gruber and Wise, D. A. (eds.), Social Security and Retirement around the World, (London: University of Chicago Press), pp. 437-474.

Evans, D. S. and Leighton, L. S. (1989) Why do smaller firms pay less?, Journal of Human Resources, 24, pp. 299-318. 
Filer, R. K. and Petri, P. A. (1998) A Job Characteristics Theory of Retirement, Review of Economics and Statistics, 70 (1), pp. 123-129.

Fuchs, V. R. (1982) Self-employment and labor force participation of older males, Journal of Human Resources, 17 (3), pp. 339-357.

Gill, I. S.; Packard, T. and Yermo, J. (2004) Keeping the Promise of Social Security in Latin America, (Washington DC: Stanford University Press and the World Bank).

Gronau, R. (1973) The Effect of Children on the Housewife's Value of Time, Journal of Political Economy, 81 (2), pp. S168-S199.

Gruber, J. and Wise, D. A. (1999), Social Security and Retirement around the World, London: University of Chicago Press.

Haider, S. and Loughran, D. (2001) Elderly Labor Supply: Work or Play?, Working Paper CRR WP 2001-4, (Chestnut Hill, MA: Centre for Retirement Research at Boston College).

Haider, S. and Loughran, D. (2003) How Important are Wages to the Elderly? Evidence from the New Beneficiary Data System and the Social Security Earnings Test, Working Paper WP 2003-049, (Michigan: Michigan Retirement Research Center, University of Michigan).

Hanoch, G. and Honig, M. (1983) Retirement, Wages, and Labor Supply of the Elderly, Journal of Labor Economics, 1 (2), pp. 131-151.

Heckman, J. J. (1974) Shadow Prices, Market Wages and Labor Supply, Econometrica, 42 (4), pp. 679-694.

Heckman, J. J. (1976) The common structure of statistical models of truncation, sample selection and limited dependent variables and a simple estimator for such models, Annals of Economic and Social Measurement, 5 (4), pp. 475-492.

Holzman, R.; Robalino, D. and Takayama, N. (2009) Closing the Coverage Gap. The role of social pensions and other retirement income transfers, (Washington DC: The World Bank).

Hurd, M. and McGarry, K. (1993) The relationship between job characteristics and retirement, Working Paper 4558, (Cambridge, M.A.: National Bureau of Economic Research).

Hurd, M. D. (1990a) The Joint Retirement Decision of Husbands and Wives, in D. Wise (ed.) Issues in the Economics of Aging, (Chicago: University of Chicago Press), pp. 231254.

Hurd, M. D. (1990b) Research on the Elderly: Economic Status, Retirement, and Consumption and Saving, Journal of Economic Literature, 28, pp. 565-637.

Hutchens, R. M. (1988) Do job opportunities decline with age?, Industrial and Labor Relations Review, 42 (1), pp. 89-99.

Kochar, A. (1999) Evaluating Familial Support for the Elderly: The Intrahousehold Allocation of Medical Expenditures in Rural Pakistan, Economic Development and Cultural Change, 47 (3), pp. 621-656.

Maurizio, R. (2009) Políticas de transferencias monetarias en Argentina: Evaluación de su impacto sobre la pobreza y la desigualdad, y evaluación de sus costos, in S. Keufman (ed.) Reflexiones y propuestas para mejorar la distribución de ingresos en Argentina, (Buenos Aires: OIT), pp. 181-266.

Maurizio, R.; Perrot, B. and Villafane, S. (2007) Dinámica de la pobreza y mercado de trabajo en la Argentina post-convertibilidad, (Buenos Aires: Ministerio del Trabajo).

Mitchell, O. S. and Fields, G. S. (1984) The Economics of Retirement Behavior, Journal of Labor Economics, 2 (1), pp. 84-105.

Parker, S. W. (1999) Elderly Health and Salaries in the Mexican Labor Market, Working Paper R-353, (Washington DC: Inter-American Development Bank). 
Paz, J. (2003) Movilidad entre empleos protegidos y no protegidos en la Argentina, in Ministerio del Trabajo and OIT (eds.), Historias Laborales de la Seguridad Social, (Buenos Aires: Ministerio del Trabajo), pp. 97-126.

Pencavel, J. (1986) Labor Supply of Men: A Survey, in O. Ashenfelter and Layard, R. (eds.), Handbook of Labor Economics, (Amsterdam: North-Holland), pp. 3-102.

Pozzebon, S. and Mitchell, O. S. (1989) Married women's retirement behavior, Journal of Population Economics, 2, pp. 39-53.

Rofman, R. (2004), Social security and the economic crisis in Argentina, mimeo, Washington DC: The World Bank.

Williamson, J. B. and McNamara, T. K. (2001), Why some workers remain in the labor force beyond the typical age of retirement?, Working Paper CRR WP 2001-09, (Chestnut Hill, MA: Centre for Retirement Research). 


\section{ENDNOTES}

${ }^{1}$ Bertranou (2001) constructs a time series with data from the metropolitan region (Gran Buenos Aires) covering the period 1974 to 1999 and finds that activity rates for women aged 65 and over increased from around 5 percent at the start of the period to just above 8 percent in 1999, and for males from just under 20 percent to just over 25 percent over the same period.

${ }^{2}$ Other factors are important too. Recent research in the USA, using extended panel data, finds that work preferences are stronger than economic need among individuals who return to work after retirement (Haider and Loughran 2001; Williamson and McNamara 2001; Haider and Loughran 2003).

${ }^{3}$ In developed countries, studies have looked at joint retirement decisions by couples (Burtless and Moffitt 1985; Pozzebon and Mitchell 1989; Hurd 1990a);

${ }^{4}$ Evidence for the USA suggests that older women are more likely to participate if they have earlier and continued work attachment (Haider and Loughran 2001).

${ }^{5}$ It is important to note the high number of refused interviews. Of the target sample of 5,427 households with older people in the ETEEP survey, 1,800 households refused to be interviewed. In a further 613 households the respondent was absent or incapacitated.

${ }^{6}$ A further 1.5 percent stated that their pensions were sufficient but that they needed more income.

${ }^{7}$ Studies of contributory pensions pay particular attention to the age of retirement specified by the pension rules (Alós, Apella, Grushka et al. 2008). In the case of Argentina this is 60 for men and 65 for women. There are indications that the retirement age rule is being applied more strictly and that financial conditions are making early retirement less attractive, but there is considerable variation in the age of first contributory pension receipt in the sample, with around one third of respondents reporting having received a pension before age 60 and a further quarter reporting having received it after age 66. And of course the specified retirement ages above do not apply to disability, survivor, and non-contributory pensions. Of those reporting being in receipt of a pension, one half have old age or service pensions, and the other half have disability, survivor, and non-contributory pensions.

${ }^{8}$ Considering males only, it is an issue whether a significant number of 60-64 year-olds expects to retire at age 65 and that as a consequence their participation propensities cannot be extrapolated to males aged 65 and over. Of the 428 males participating in the labour market in the sample, 204 are aged 60-64. However, a more detailed look at this group suggests this is not an important issue in practice. Of the 204 males aged 60-64, 73 are self-employed, and 54 among the rest report not having retired due to insufficient years of contribution. Only a further 54 are waiting to fulfil the age requirement, and 4 report their pension being processed. It is, of course, not possible to predict whether they will work after receiving their pensions. The analysis below will therefore use the full sample of males. 


\footnotetext{
${ }^{9}$ Alternatively, the model was estimated with higher powers of age, squared and cubic, but they did not generate significant coefficients.

${ }^{10}$ To check for potential endogeneity arising from household dynamics around the receipt of pension benefits, the participation probit was estimated excluding respondents who had moved in the last 4 years. The resulting coefficients were almost identical to those estimated without the sample restriction.

${ }^{11}$ See footnote 12 .

${ }^{12}$ As a check on whether missing observations on earnings are likely to generate biases in predicted earnings, it is now possible to compare the distribution of participants with and without reported earnings along predicted earnings. It was found that, for both the full sample and the sample of males only, participants with non-reported earnings were distributed in a similar fashion to those with reported earnings. This applies particularly to the higher deciles of potential earnings that are more populated by participants. This suggests that, in terms of their potential earnings, those without reported earnings are unlikely to be significantly different from those with reported earnings.

${ }^{13}$ The Social Protection Inclusion Plan includes other measures directed at children and poor households.
} 
Figure 1. Labour market participation rates by age. Argentina 1997-2004

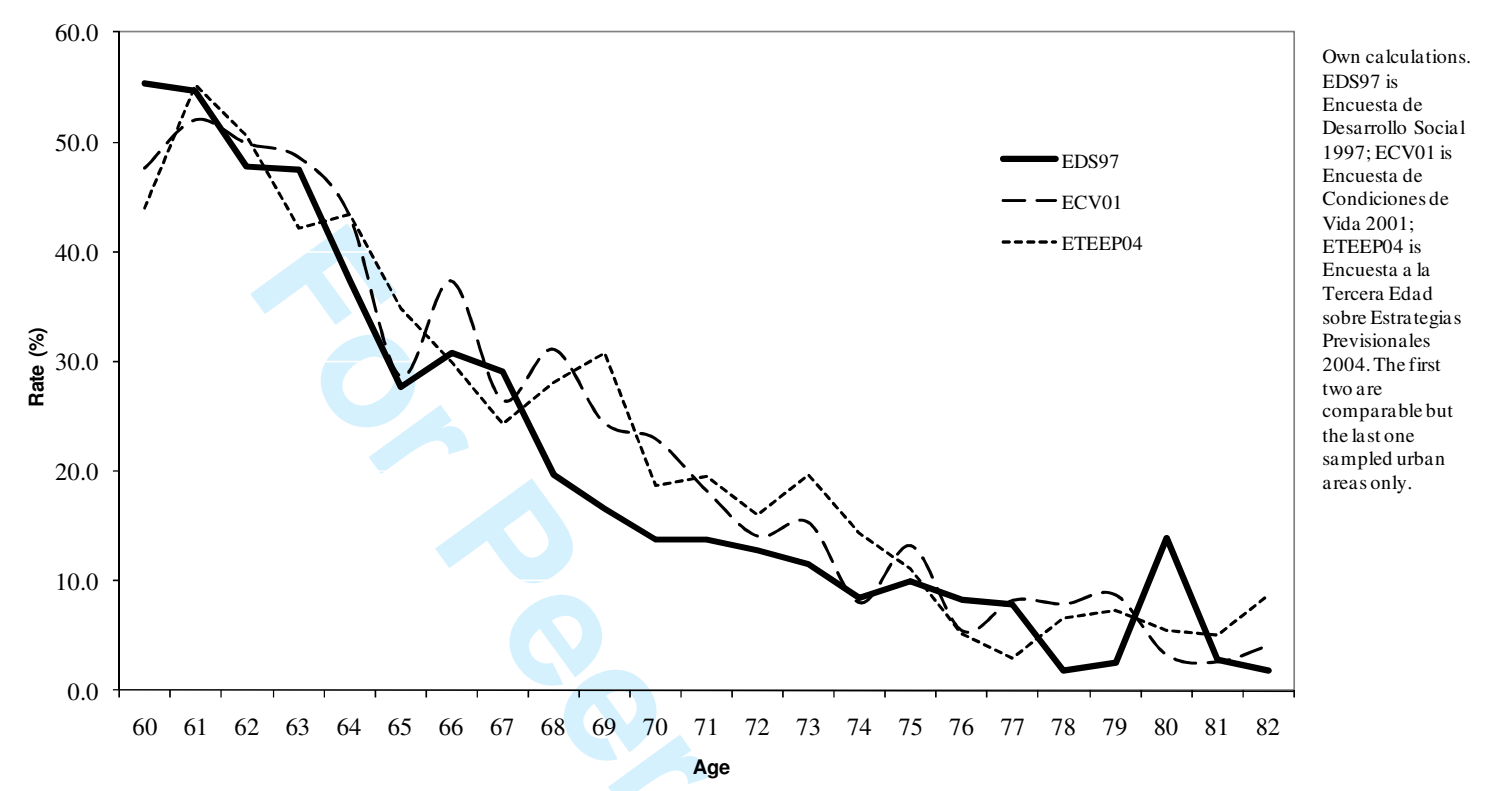


Figure 2. Population aged 60 and over by activity and pension receipt status. Argentina ETEEP Survey 2003

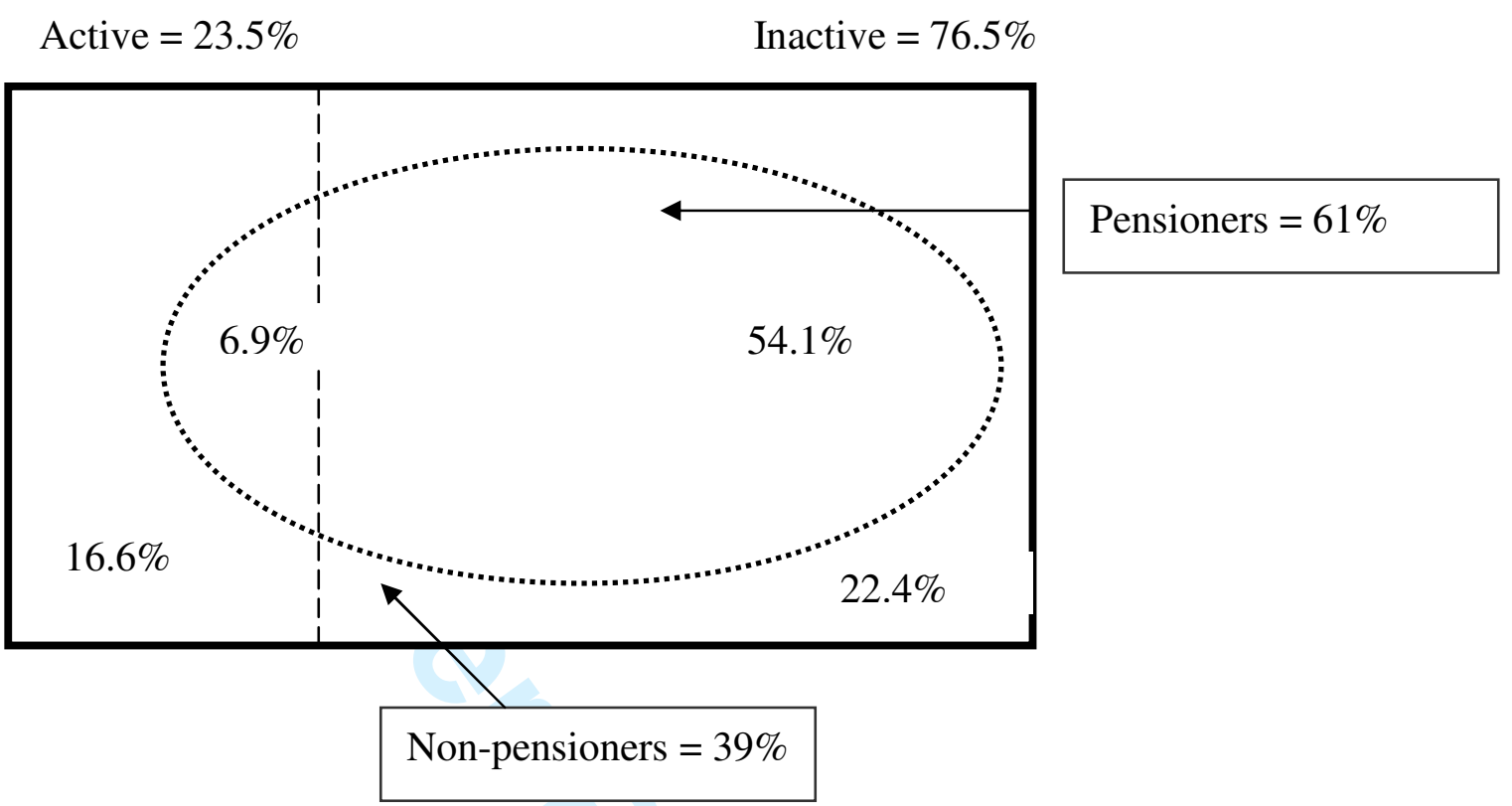




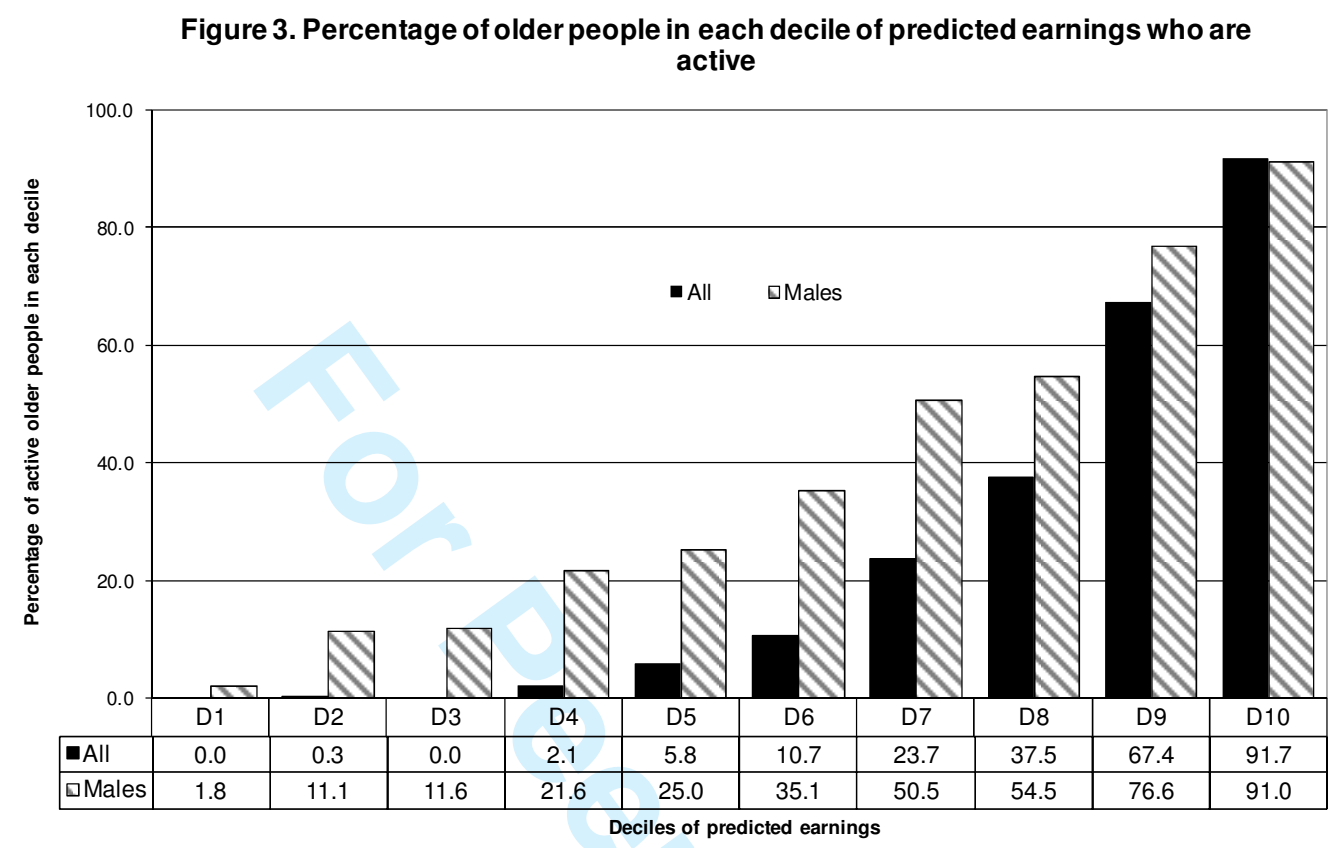


Figure 4. Distribution of active older people in deciles of predicted earnings

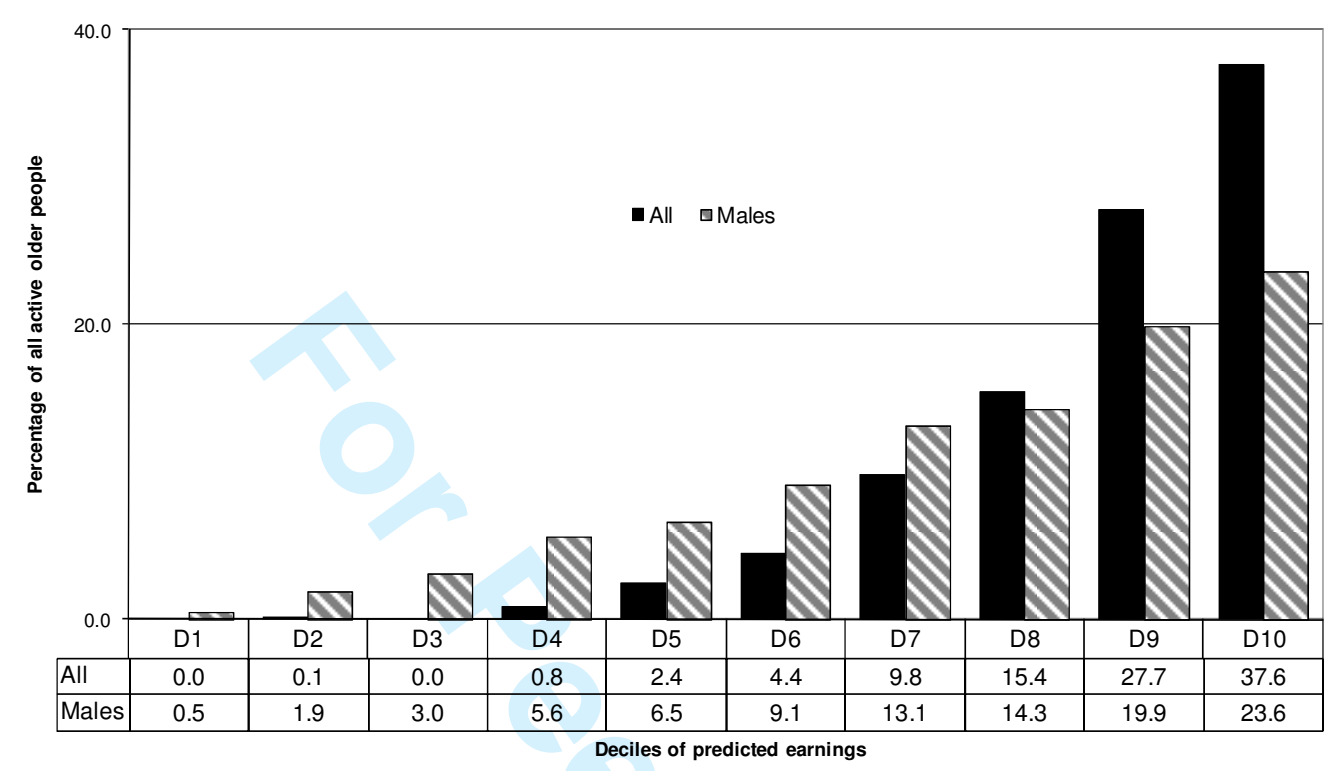


Table 1. Summary of results from participation probits

(Dependent variable is 1 for participants, 0 otherwise; Marginal effects are reported)

\begin{tabular}{|c|c|c|c|c|c|c|}
\hline \multirow[b]{2}{*}{ Variable } & \multicolumn{3}{|c|}{$\begin{array}{c}\text { Full Sample } \\
\mathrm{n}=2910 \\
\mathrm{LL}=-1152 ; \mathrm{LL}(0)=-1600\end{array}$} & \multicolumn{3}{|c|}{$\begin{array}{c}\text { Men } \\
\mathrm{n}=1114 \\
\mathrm{LL}=-546 ; \mathrm{LL}(0)=-740\end{array}$} \\
\hline & Marginal & Std.error & Mean & Marginal & Std.error & Mean \\
\hline Age & $-0.020 *$ & 0.001 & 70.9 & $-0.035^{*}$ & 0.002 & 70.2 \\
\hline Male & $0.149 *$ & 0.022 & 0.38 & & & \\
\hline Poor health & $-0.070 *$ & 0.018 & 0.13 & $-0.188 *$ & 0.041 & 0.11 \\
\hline Good health & $0.050 *$ & 0.015 & 0.46 & $0.070 * *$ & 0.034 & 0.52 \\
\hline $\begin{array}{l}\text { Number of } \\
\text { pensioners in } \\
\text { household }\end{array}$ & $-.0 .055^{*}$ & 0.017 & 0.22 & $-0.099 * *$ & 0.041 & 0.15 \\
\hline $\begin{array}{l}\text { Number of distress } \\
\text { strategies }\end{array}$ & $0.035^{*}$ & 0.010 & 0.33 & $0.048 * *$ & 0.017 & 0.53 \\
\hline Contribution density & $-0.127 *$ & 0.019 & 0.44 & $-0.300 *$ & 0.045 & 0.65 \\
\hline Work density & $0.237 *$ & 0.026 & 0.57 & $0.243^{*}$ & 0.079 & 0.79 \\
\hline Occupation controls & yes & yes & yes & yes & yes & yes \\
\hline Region controls & yes & yes & yes & yes & yes & yes \\
\hline
\end{tabular}

The model estimated also included primary and higher education, single, widow, support ratio, numbers of active household members and household size variables. $*$ means significant at $1 \% ; * *$ at $5 \%$. 
Table 2. Summary of results from the estimation of earnings models

(Dependent variable is the natural log of aggregate monthly earnings)

\begin{tabular}{|c|c|c|c|c|c|c|}
\hline \multirow[b]{2}{*}{ Variable } & \multicolumn{3}{|c|}{$\begin{array}{c}\text { Full Sample } \\
n=360 \\
\text { Adj. } \mathrm{R} 2=0.4313\end{array}$} & \multicolumn{3}{|c|}{$\begin{array}{c}\text { Men } \\
n=217 \\
\text { Adj. } \mathrm{R} 2=0.3813\end{array}$} \\
\hline & Coeffic. & $t$-stat & Mean & Coeffic. & $t$-stat & Mean \\
\hline Constant & $8.423^{*}$ & 8.265 & & $8.480 *$ & 5.662 & \\
\hline Age & $-0.074 *$ & -3.346 & 65.63 & $-0.062 * *$ & -2.410 & 65.28 \\
\hline Male & $0.648^{*}$ & 3.741 & 0.60 & & & \\
\hline Married & -0.105 & -0.640 & 0.55 & 0.224 & 0.992 & 0.70 \\
\hline Single & $-0.498 * *$ & -2.347 & 0.08 & -0.169 & -0.561 & 0.07 \\
\hline Widow & -0.132 & -0.756 & 0.24 & -0.009 & -0.034 & 0.13 \\
\hline Primary School & -0.128 & -1.146 & 0.66 & $-0.358^{*}$ & -2.837 & 0.64 \\
\hline Higher Education & $0.853^{*}$ & 3.526 & 0.05 & $0.761 *$ & 2.659 & 0.05 \\
\hline Poor Health & $-0.397 * *$ & -2.098 & 0.07 & -0.221 & -0.813 & 0.05 \\
\hline Good Health & $0.349 *$ & 3.262 & 0.57 & $0.363 *$ & 2.809 & 0.63 \\
\hline Self-employed & $-0.482 *$ & -4.532 & 0.47 & $-0.560 *$ & -4.287 & 0.52 \\
\hline Employer & 0.340 & 1.322 & 0.03 & $0.587 * * *$ & 1.949 & 0.05 \\
\hline Contribution density & $0.449 * *$ & 2.389 & 0.47 & 0.374 & 1.440 & 0.55 \\
\hline Work density & $1.448 *$ & 4.885 & 0.78 & $1.538 *$ & 4.476 & 0.82 \\
\hline Size of establishment & $-0.104 * * *$ & -1.757 & 1.48 & $-0.128 * * *$ & -1.757 & 1.5 \\
\hline Lambda & $0.705^{* *}$ & 2.203 & 0.87 & 0.494 & 1.307 & 0.67 \\
\hline Occupation controls & yes & yes & yes & yes & yes & yes \\
\hline Region controls & yes & yes & yes & yes & yes & yes \\
\hline
\end{tabular}

The model estimated also included primary and higher education, single, and widow variables.

$*$ means significant at $1 \%$;** at $5 \%$; ** at $10 \%$ 


\section{APPENDIX 1. VARIABLE DEFINITIONS}

\section{Table A1.1. Variable definitions}

\begin{tabular}{|c|c|}
\hline Age & Age in years \\
\hline Male & Whether male \\
\hline Married & Whether married or in union \\
\hline Single & Whether single \\
\hline Widow & Whether widow/er \\
\hline Primary & Whether attended primary education \\
\hline Secondary & Whether attended secondary education \\
\hline Higher education & Whether attended higher education \\
\hline Poor health & Whether reported being in poor or very poor health \\
\hline Good health & Whether reported being in good or very good health \\
\hline Support ratio & $\begin{array}{l}\text { Support ratio: adults (15-59) over children below } 15 \text { plus older } \\
\text { people } 60 \text { and over in household }\end{array}$ \\
\hline Household size & Number of persons in household \\
\hline $\begin{array}{l}\text { Numbers active in } \\
\text { household }\end{array}$ & Number of active persons in household other than respondent \\
\hline $\begin{array}{l}\text { Number of pensioners in } \\
\text { household }\end{array}$ & $\begin{array}{l}\text { Number of pensioners (receiving any pension) in household other } \\
\text { than respondent }\end{array}$ \\
\hline $\begin{array}{l}\text { Number of distress } \\
\text { strategies }\end{array}$ & $\begin{array}{l}\text { Number of financial distress strategies used in last three months } \\
\text { from a list of three. Whether had to: borrow from family and } \\
\text { friends; use consumer credit; or sell belongings }\end{array}$ \\
\hline Self-employed & Whether self-employed in last job \\
\hline Employee & Whether employee in last job \\
\hline Employer & Whether employer in last job \\
\hline Contribution density & $\begin{array}{l}\text { Contribution density measured as reported years of contributed in } \\
\text { all jobs over working life as a fraction of numbers of years of work } \\
\text { reported in all jobs during working life }\end{array}$ \\
\hline Work density & $\begin{array}{l}\text { Work density measured as number of years worked in all self- } \\
\text { reported by respondent as a fraction of working age calculated as } \\
18-60 \text { for women and } 18-65 \text { for men }\end{array}$ \\
\hline Size of establishment & Size of establishment in last job \\
\hline Occupation1 & Agriculture, livestock, and fishing \\
\hline Occupation2 & Mining, Oil and Gas \\
\hline Occupation3 & Manufacturing: Food, drink and tobacco \\
\hline Occupation 4 & Manufacturing: textiles and leather goods \\
\hline Occupation5 & Manufacturing: Chemical \\
\hline Occupation6 & Manufacturing: Metal \\
\hline Occupation7 & Manufacturing: Other \\
\hline Occupation8 & Electricity, gas and water \\
\hline Occupation9 & Construction \\
\hline Occupation10 & Commercial services, and repairs of vehicles and other \\
\hline Occupation11 & Hotels, restaurants and bars \\
\hline Occupation12 & Transport, telecommunications and travel \\
\hline Occupation13 & Financial Services \\
\hline Occupation14 & Public Administration and defence \\
\hline
\end{tabular}




\begin{tabular}{l|l}
\hline \hline Occupation15 & Education, health and social services \\
\hline Occupation16 & $\begin{array}{l}\text { Leisure, culture, sports, and community and personal services } \\
\text { including domestic service }\end{array}$ \\
\hline Region1 & Buenos Aires and Metropolitan Area \\
\hline Region2 & Cuyo \\
\hline Region3 & North-East \\
\hline Region4 & North-West \\
\hline Region5 & Pampeana \\
\hline \hline
\end{tabular}

